\title{
8. Some initial theorizing
}

In 1989 I wrote a pamphlet, entitled Monetarism Lost, for the Centre for Policy Studies. It gave a narrative account of how and why the monetarist approach to economic management had been dropped in 1985, and attributed the subsequent boom to excessive monetary growth. It was very thin on theory. In his review of the pamphlet in the Financial Times (on 6 June 1989) Mr Samuel Brittan nevertheless remarked: 'Tim Congdon deserves credit for spotting the present UK inflationary boom long before most others, at least partly for the right reasons. The difficulty of presenting him with his Oscar is that he insists on using the award ceremony to promulgate his general system, which is more dubious.' I assume Mr Brittan's reference to a 'general system' may have been prompted by some of my other writings, although I am not sure which ones. In this chapter I give an attempt to set out, in loosely theoretical terms, how I think the economy works. The main paper is based on a lecture on 'Money' I gave in 1988 at the invitation of the Economic Research Council, and published in 1990 in a book, Reflections on Money, edited by Professor David Llewellyn.

It is indeed possible - as Mr Brittan implies - that I was right about the Lawson boom because of a fluke. However, I would like to think that my accurate prognosis reflected a good analytical understanding of how the economy works. If it were impossible to identify in general terms what had gone wrong with official policy in these years, there would be little hope of avoiding similar mistakes in the future. There should be some mileage in trying to extract wider lessons from recent experience. I believe that my approach to analysing the British economy in the 1970s and 1980s, with its strong emphasis on credit and broad money, was better than the alternatives.

The focus of recent debates has been the importance of monetary policy for the economy's behaviour. There are two main schools of thought, although each has several variants. According to the first ('monetarist'), the level of spending in the economy is determined mainly by monetary variables and, usually, by a particular monetary aggregate. I tend to be categorized as a 'monetarist' in public debate and have been unable to avoid this practice in previous chapters. But, in fact, this label is misleading and a nuisance. I would like the sort of monetarist who thinks that money GDP is determined by M0 (or M3 or M4) to be called a 'naive monetarist' and his sort of 
analysis 'naive monetarism'. According to the second school of thought ('Keynesian'), the level of spending is determined by a number of variables (such as tax rates, world trade and interest rates), whose relative importance is best assessed by carrying out statistical tests on past data. (In Britain this 'Keynesianism' has become so diluted from the original Keynes that it might as well be called 'pragmatic' or 'pragmatic Keynesian'.)

The naive monetarist approach is very simple in structure. It is judged from econometric estimation - that one monetary aggregate (M0, M1, noninterest-bearing $\mathrm{M} 1$ or whatever) has a particularly reliable link with expenditure and incomes. So, if economists track this aggregate, they should have a good idea of what is happening to the economy now, and what will happen in the future. The approach includes among its supporters Professor Patrick Minford of Liverpool University (who is keen on M0), Sir Alan Walters (who is also keen on M0, but admires M1 as well) and Professor Gordon Pepper (who sometimes prefers narrow money to broad money). Typically, monetarist economists of this kind do not feel obliged to produce forecasts of the various components of demand, such as consumption and investment, because they are doubtful that enough is understood to make sensible statements about the detailed national income arithmetic.

By contrast, Keynesian/pragmatic analysis can become quite complicated. Spending is split into various categories, such as consumption, investment, stockbuilding, exports and imports, and government spending. The key is to identify the major influences on these various categories of expenditure. These influences are called 'exogenous variables' and can be quite various. Once econometric tests have established which exogenous variables have been most important in the past, their role is incorporated into a set of equations (known as 'expenditure equations'). Usually econometric work is unable to identify a strong link between any monetary aggregate and any category of spending. The role of money in the economy comes to be regarded as incidental and is sometimes dismissed as of no importance. The National Institute of Economic and Social Research exemplifies this point of view most completely, although there are traces of it in a number of City analysts, including, for instance, Mr Gavyn Davies of Goldman Sachs, who often pours scorn on the Ms.

My approach is different from that of both naive monetarism and pragmatic Keynesianism. The starting-point of my analysis is that money is of great importance to the economy, which sets me apart from the Keynesians. But unlike the naive monetarists I try to explain how the quantity of money is determined, and I agree with the Keynesians about the need to have expenditure equations determining consumption, investment and so on. Moreover, I am not happy to use a monetary aggregate because it has had a good relationship with national income in the past. The trouble here is that 
the monetary aggregate may be determined by money national income, rather than national income by the monetary aggregate. For me it is essential also to look at the balance sheets of particular agents in the economy - that is, individuals, companies, financial institutions and so on. Sharp changes in monetary growth and asset prices can disturb balance sheets, and provoke major changes in behaviour. In this context the only relevant definition of money is a broad measure, which includes all deposits. I therefore pay great attention to the growth of credit, because it is this which determines the growth of broad money. The structure of my approach to macroeconomic analysis is contrasted to that of the naive monetarists and pragmatic Keynesians in Figs 8.1-8.3.

My approach is certainly not 'monetarist' in the strict Chicago sense of the term. It does not see the quantity of money as being determined by some multiple of the banks' cash reserves and it identifies monetary disequilibrium as a key motive force behind macroeconomic fluctuations. It might be better seen as harking back to the trade cycle literature before the development of Keynesian macroeconomics in the 1950s and 1960s, even perhaps to the Banking School of the early 19th century. (There was a debate between the Banking and Currency Schools about how best to conduct monetary policy.)

\section{Figure 8.1 Structure of naive monetarist model}

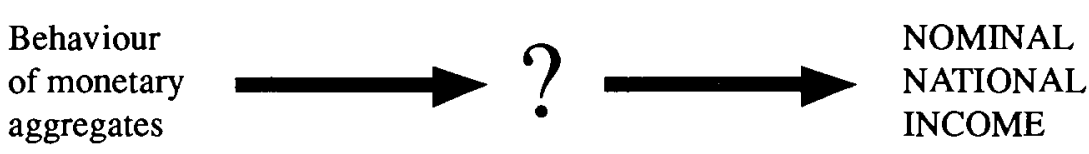

The question mark is to point out the 'black box' - i.e. the failure to explain the transmission mechanism - in naive monetarism.

Figure 8.2 Structure of standard Keynesian/pragmatic model
Exogenous/independent
variables variables
Budget deficit
World trade
Interest rates
Forecasting equations
SPENDING
Other influences

Endogenous/dependent 
Figure 8.3 An alternative approach: how credit, money and balance sheets affect economic activity

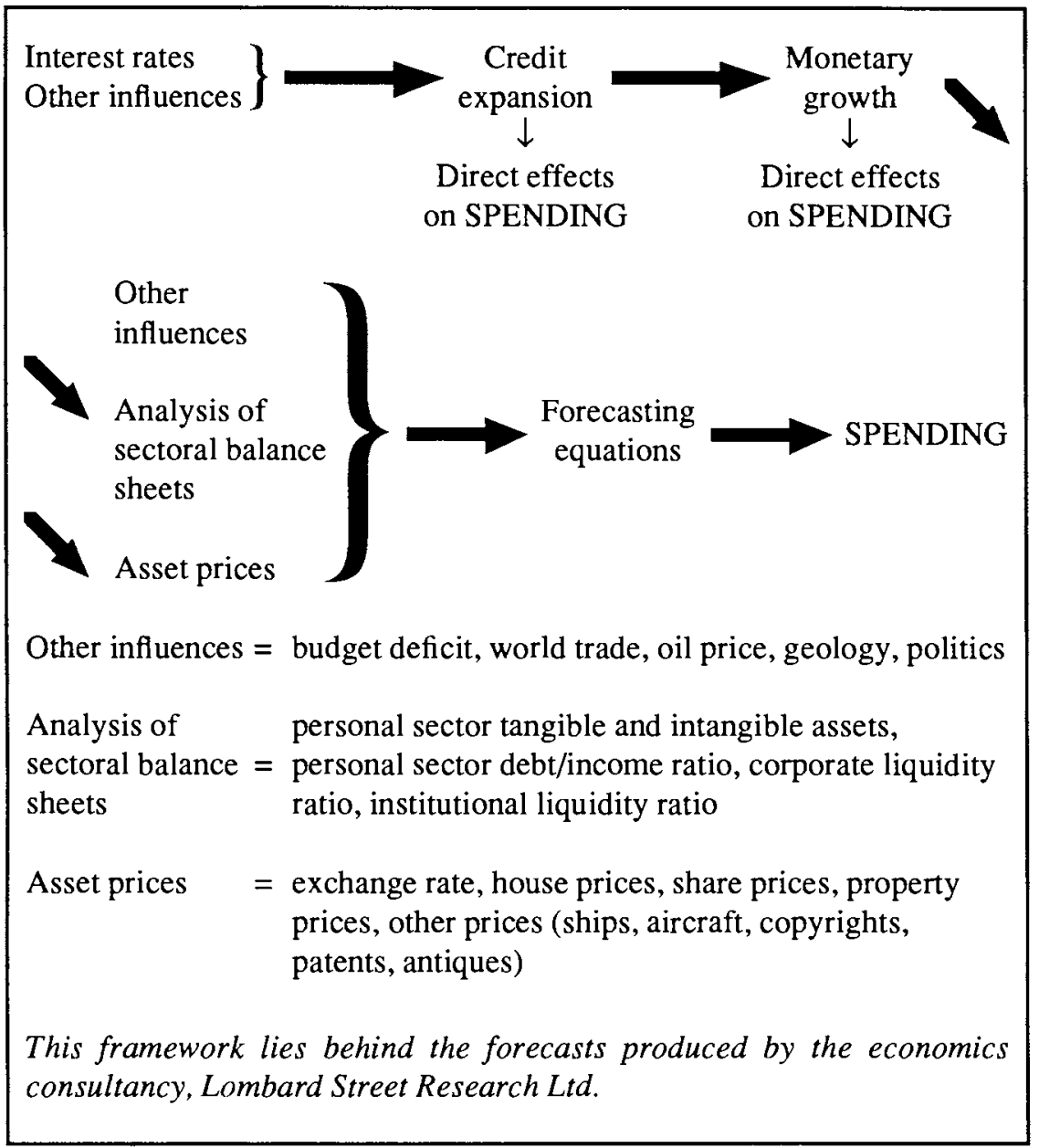

Further, an argument could be made that my line of thought is closer to Keynes than Keynes is to the so-called 'Keynesians' today.

Although I am sceptical about large-scale econometric models, I decided in 1986 that I would have to develop one. Participants in the public debate are hallucinated by their computer power, econometric jargon and apparent precision into believing that forecasts from such models have a stronger claim to be taken seriously than other kinds of statement about the economy. For my so-called 'monetarist' warnings to be given any credence, I felt that I also had to produce a large-scale macroeconomic forecast. I was very fortu- 
nate that Dr Peter Warburton (now Chief Economist at Robert Fleming) joined my economics team at $\mathrm{L}$. Messel \& Co. and later Shearson Lehman. (L. Messel \& Co. was taken over by Shearson and lost its identity in 1987.)

Dr Warburton had considerable econometric experience in building the London Business School model in the late 1970s and early 1980s. With his help, I prepared macroeconomic forecasts from October 1986 to June 1988. I am glad to say that we produced the most accurate forecasts of the British economy for both 1987 and 1988. After leaving Shearson Lehman, I established in 1989 a small economic forecasting consultancy, Lombard Street Research Ltd, with help from Gerrard \& National. Its forecast of the British economy for 1990 was also excellent and came close to being the most accurate available.

The other piece reprinted here, 'The importance of money in macroeconomic forecasting - part 2', explains - in a journalistic way - why the Treasury misled Mr. Lawson with its economic forecasts in the late 1980s, just as it had misled Mr. Barber in the early 1970s.

\section{Credit, Broad Money and Economic Activity}

Reprinted from a paper, 'Credit, broad money and the economy', published in D. Llewellyn (ed.) Reflections on Money (London: Macmillan), 1990, with minor amendments.

The key point of this paper is that macroeconomic analysis cannot proceed sensibly without a discussion of monetary equilibrium. (I would guess that 90 per cent of practising British macroeconomists hardly ever think about 'monetary equilibrium'. Many of them would not even know what is meant by the phrase.) Moreover, the attainment of monetary equilibrium is only interesting if the monetary concept under consideration is broad money. In a modern economy the growth of broad money is determined by the growth of bank credit.

British macroeconomics is in a mess. There is much confusion about how demand, output and inflation are determined, with economists constantly squabbling among themselves about the relative importance of different influences. The disputes are not of merely academic and theoretical interest. The lack of a consensus about 'how the economy really works' was largely responsible for the failure of both official and private forecasters to see that the financial excesses of 1987 and 1988 would lead to the inflation and balance-of-payments problems of 1989 and 1990. This failure also had vital implications for financial markets. The credit and monetary excesses had to 
be countered by an increase in interest rates in late 1988 which was a shock in its scale and timing, and interest rates have subsequently had to stay higher for longer than anyone expected. The focus of these debates has been the importance of monetary policy for the economy's behaviour. One source of disagreement has been the lack of clarity about the precise meaning of credit and money, and about their implications for the economy.

The objective of the present paper is to clarify and resolve some of the key issues. It has two main themes. The first is that, in modern circumstances, the growth of money is driven by the growth of credit. Money and credit are nevertheless distinct and separate categories, and should not be confused. The second is that, in any economy, the amount of money has a strong and definite link with the amount of spending. As a result, when the amount of money changes sharply, there are profound short-run effects on the way people and companies behave, and so on the level of economic activity. In the long run, however, money cannot alter the economy's ability to produce real output, and changes in the quantity of money mainly affect the price level.

Professor Goodhart has noted that historically money has taken a great variety of exotic forms, including such objects as red feathers and cowrie shells. ${ }^{1}$ The evolution of money is a fascinating and important subject, and one of its main lessons needs to be strongly emphasized. This is that in the past societies have used such a diverse range of things as 'money' that grand generalizations in monetary economics should be treated with suspicion. The discussion here will be confined to the circumstances of a modern economy with banks and a central bank. The aim will be to provide an account (a 'special theory') of credit and money that is valid in contemporary market-based industrial economies. The same story could not be told in a pre-modern economy without banks or central banks; nor would it be altogether convincing today in a poor developing country or in a command economy like the former Soviet Union's; and it might be totally misleading as a description of the operation of high-tech economies in the future.

\section{Money is a liability of the financial system}

The first point to highlight in a definition of money is that money has to be recognized as such by large numbers of people. Esoteric objects such as Chinese porcelain vases or Byzantine icons may be 'worth a lot of money', but they are not money as such. They could not be used to buy groceries from a corner shop or timber from a builders' merchant. Instead money comprises a fairly limited range of assets which can be used to pay for goods and services everywhere within a particular monetary area.

There is another key dimension to the definition of money. Goodhart has argued that money consists of 'those assets that represent a means of pay- 
ment'. ${ }^{2}$ The remark might seem straightforward enough, but he added a subtle and vital amplification. This was to say that one characteristic of such assets was that their transfer 'completes a transaction'. By so doing, Professor Goodhart excluded credit facilities, which allow a transaction to take place but still leave a debt to be settled.

It is obvious that notes and coin are money under this definition. If payments are made with notes and coin, purchases are completed when they are handed over to the vendor. The purchaser has the goods, the vendor has the money and nothing remains to be done. Again, if payments are made by cheque against bank deposits, the purchaser has the goods, the vendor has the cheque, the purchaser's bank deposit is debited by a particular amount, the vendor is credited by the same amount, and nothing remains to be done. But, if payments are made by cheque against a loan facility, the purchaser has the goods, the vendor has the cheque, the purchaser's loan account is debited by a particular amount, the vendor is credited by the same amount and the purchaser has to repay the bank at some future date. In this final example, the transaction is not completed even when the cheque has been cleared. It follows that notes, coin and bank deposits are money, but loan facilities are not. Similarly, proofs of creditworthiness (such as credit cards) may greatly reduce the inconvenience of buying and selling, but they are not money. We have here a very sharp distinction between credit facilities and money assets. There is no need for confusion.

Indeed, it is sufficient for most purposes to think of money as constituted by notes, coin and deposits. The issue can be complicated by devising different definitions of money, each of which includes a specific range of monetary assets. Thus, we can think of an aggregate which consists of only notes and coin, and call it M0. Or we can think of another which includes notes, coin and deposits (so-called 'sight deposits') which can be spent without giving advance notice to a bank, and call it M1. In fact, in the UK today there are six Ms, ranging from M0 to M5. The higher is the number attached to an $M$, the greater is the range of money assets included and the larger is the money supply concept under consideration. M0 and M1 are commonly called the 'narrow' definitions; M2 is an intermediate measure, usually described as consisting of transactions balances; and M3, M4 and M5 are measures of 'broad money'. But the basic idea - that money consists of notes, coin and deposits, and the money supply may be defined as some mix of these ingredients - is straightforward.

It is clear that notes, coin and deposits share the characteristic that they can be used to pay for goods, services and assets. But, in a modern economy, they also have something else in common. This is that they are liabilities of financial institutions, particularly the banks. Thus, notes are issued by, and are a liability of, the Bank of England. Similarly, if money is held in a bank 
deposit, the bank owes money to the depositor and must follow instructions with regard to payments. The bank deposits are evidently the banks' liabilities. Finally, since it is increasingly possible nowadays to write cheques against building society deposits, they are beginning to resemble bank deposits and can properly be regarded as money. But they also are liabilities, this time of the building societies.

It may seem unnecessary to labour the point that nowadays all forms of money are liabilities of financial organizations. But there is an important reason for emphasizing it. By so doing, we are alerted to the uniqueness of the monetary system in a modern economy. In earlier times (such as the eras of red feathers and cowrie shells), money was not a liability of financial systems, but a commodity. In other words, money had value not because a particular bank recognized an obligation to its depositors or holders of its notes, but because the commodity had intrinsic worth. The realization that money could perform its functions without being a specific commodity was one of the key institutional innovations which made possible the emergence of advanced industrial economies.

Despite the benefits of modern monetary arrangements, nostalgia for commodity money is widespread and deeply rooted. It takes two particularly notable forms. First, sceptics of governments' ability to manage 'paper money' yearn for the financial stability commonly, although perhaps mistakenly, attributed to the gold standard. Secondly, some economists (including such well-known monetarists as Milton Friedman and Karl Brunner) continue to theorize about economies with commodity money, apparently unaware that this approach is not fully applicable to economies with paper money. There is not enough space here to explain the difficulties to which this confusion gives rise. It is sufficient to say that many of the most heated debates in monetary economics stem from a lack of clarity about whether propositions relate to commodity-money or paper-money economies. ${ }^{3}$ The discussion in the rest of this chapter relates to a modern economy in which money is explicitly a liability of financial institutions.

\section{A key distinction}

Before we discuss the creation of money, one more idea needs to be developed. Although notes, coin and bank deposits are all money, a sharp distinction should be drawn between two forms that they take. Certain kinds of money are legal tender and must be accepted in law as a means of payment. In the UK today, these are represented by coins (a liability of the Royal Mint) and notes (a liability of the Bank of England). But there are other kinds of money which are not legal tender, and it is not an offence to refuse payment in them. 
Thus, I am fully within my rights to turn down someone's cheque. The writer of the cheque has no legal redress against me or against his bank. In effect, when I refuse a cheque I am indicating two things. First, I am not convinced that the writer of the cheque has enough legal tender in his bank account to honour the cheque and, secondly, if he does not in fact have enough legal tender, I am not prepared to hold a claim on the bank concerned. In some circumstances - for example, when a cheque is drawn on a bogus bank without capital or assets - I would be a fool to accept a cheque instead of legal tender. In the UK today we can, for virtually all practical purposes, regard notes and coin as legal tender, while other forms of money (bank deposits, building society deposits) are not. ${ }^{4}$

The last two paragraphs have a critical implication for the behaviour of interest rates. When I write a cheque, I am giving someone a mere scrap of paper. Why does this piece of paper have any value? The answer is that it is an instruction to my bank to pay the person or company named a sum in legal tender. An obvious corollary is that the bank could not conduct its business unless it held legal tender among its assets. It is true that nowadays the practice of modern banking is so sophisticated that most cheques are cleared by the cancellation of debits and credits between the banks themselves. Banks do not need to make large and cumbersome payments in notes and coin either to each other or to their customers. Nevertheless, they must have the ultimate ability to make payments in legal tender.

The imperative need for banks to meet demands on them in notes and coin is the origin of the Bank of England's power to determine interest rates. The Bank is the monopoly issuer of legal tender notes. It can therefore fix the interest rate at which these notes are borrowed and lent. ${ }^{5}$ Since bank deposits are expressed in terms of legal tender and should be fully substitutable with them, the Bank of England's interest rate (variously described as 'Bank rate', 'Minimum Lending Rate', 'seven-day dealing rate' and so on over the years) is the key interest rate in the monetary system. Since there is no other issuer of legal tender, there is no other institution which can dispute the Bank's sway over interest rates.

This conclusion is of great significance. The operation of monetary policy has been a constant topic of debate in the UK in recent years, with uncertainty about how interest rates are set being a leading source of contention. There is no need for this uncertainty. Although there are a number of details to fill in, the essential message of our argument is plain and should be uncontroversial. In a modern economy interest rates are decided by the central bank. The power to determine interest rates is derived from the central bank's position as the monopoly supplier of legal tender. Its influence over interest rates is not based on convention and it does not survive because of the commercial banks' inertia. ${ }^{6}$ Moreover, in principle, the central bank does not 
have to pay the slightest attention to 'market views'. It is true that, in the real world, central bankers are not known for intellectual iconoclasm and therefore try to respect the market consensus about where interest rates should be. But it is also true that there is nothing logically inevitable about this interplay of ideas between the markets and the authorities. ${ }^{7}$

\section{Money is created by credit}

The nature of money in a modern economy - that it is a liability of financial organizations - has an important consequence. The liability side of any balance sheet can expand only if the assets side also expands. Banks and building societies increase their assets by making loans to their customers. It follows that money is created as a result of this extension of credit, while the rate of monetary growth is governed by the rate of credit expansion. In a premodern economy more money could come into being only if more of the monetary commodity was actually produced. Credit expansion, on the other hand, requires merely the simultaneous registration of debts (i.e. deposit liabilities) and assets (i.e. bank loans, mostly). The ability to create money by a stroke of a pen is strikingly efficient in cutting down on the quantity of resources needed to operate a system of payments. It constitutes a major advance in a society's productivity.

Unhappily, the negligible cost of producing money in a modern economy has the drawback that the issuers of money may be tempted to create an excessive amount. The result may be an inflationary process, with money losing value relative to other things and a consequent loss of confidence in the currency. This risk exists with privately owned banks, but it is subject to a tight constraint. Because their deposit liabilities are not legal tender, they must not allow their deposits to increase too much in relation to their holdings of legal tender. The quantity of bank deposits therefore cannot expand without limit if the quantity of legal tender is fixed or rising only gently over time. In fact, the historical record shows that bank deposits tend to be a fairly stable multiple of the amount of legal tender money over a period of five or ten years, although in the very long run institutional change can alter the relationship radically.

However, central banks are not subject to the same discipline as privatelyowned banks. If they (or their political masters) decide to issue legal tender money in reckless and inflationary profusion, they are not breaking the law and neither do they (or their political masters) have to worry about going out of business. The dangers of an inflationary overissue of credit-based money have to be balanced against the benefits to society from the trifling cost of creating it. This dilemma, which is at the heart of the controversies over monetary policy in a modern economy, is neatly captured in the title of a pamphlet, Proposals for an Economical and Secure Currency, written by the 
famous British economist, David Ricardo, in 1816. Credit-based money is economical in terms of the resources required to make it. But it is potentially insecure in value if too much of it is made. The responsibility for prudent monetary management ultimately falls on the central bank, since - as we have seen - the quantity of bank deposits cannot run out of control if the quantity of legal tender is limited.

The key points of the discussion so far may now be summarized. In a modern economy money is a liability of the financial system, particularly of the banks. Because of this property the growth of money is governed by indeed, for many practical purposes, can be equated with - the growth of bank credit. The central bank, notably the Bank of England in the UK, can try to control the quantity of money by varying the rate of interest. It has the power to determine interest rates because it is the monopoly supplier of legal tender. Privately-owned commercial banks, whose deposits are not legal tender, must kowtow to the Bank of England's interest rate decisions as they dare not risk being unable to convert their liabilities into legal tender.

We must emphasize, before we proceed to consider the impact of money on economic activity, that there is no muddle about the relationship between credit and money in our theory. To say that 'money is created by credit' is not equivalent to saying that 'money is credit'.

\section{Money and monetary equilibrium}

Once money has been brought into being by credit expansion, what is the relationship between money and economic activity? Before answering this question, it is best to digress briefly to consider the relationship between any set of objects in the economy. For example, the economy produces each year a certain number of apples and pears. Market forces - the laws of supply and demand - establish a price ratio between the two fruits which keeps their producers profitable and their consumers happy. We can call this ratio, which satisfies buyers and sellers so fully that they have no wish to change the situation, an equilibrium ratio.

If the quantity of apples rises or falls dramatically (because of the discovery of a new seed, a crop disease or whatever), but the quantity of pears stays the same, we would expect the relative price of apples and pears to change sharply. There will be another equilibrium price associated with the new supply conditions. But the passage from one equilibrium price to another may involve disturbance and uncertainty, and we would not expect the new equilibrium to be attained instantaneously.

We could tell the same story about the relative price of bricks and mortar, or coal and electricity, or any other combination of goods and services we care to think of. Associated with each equilibrium price are also particular quantities of each good. If the quantities change, it is likely that the relative 
price must also change. The essential point is that there is an equilibrium relationship, in terms of both price and quantity, between any good and all other goods. When this equilibrium holds, there is no tendency for people or companies to try to upset it. The same set of prices and quantities continues from one period to another. The economy is at rest. Only if there is an unexpected change (in demand or supply conditions) is the equilibrium broken.

It does not take much imagination to think of money as just another 'good'. Indeed, it is particularly easy to think of it in this way since the prices of all goods are expressed in terms of money. If market forces establish the relative price of apples and pears (i.e. the number of apples required to buy one pear, say, $1^{1 / 2}$ ), they also establish the relative price of apples and money (say, $6 p$ ) and the relative price of pears and money (4p). The idea can be extended and generalized. If there is an equilibrium relationship between money and any particular good, there must also be an equilibrium relationship between money and national output as a whole. When this equilibrium holds, there is a particular level of national output (expressed in terms of $£$ billion, to put the idea in a UK context) and a particular amount of money (also in $£$ billion). Associated with the equilibrium is a price level of all goods and services taken together. In monetary equilibrium the demand for money (i.e. the quantity of notes, coin and bank deposits people want to hold) is equal to the money supply (i.e. the quantity of notes, coin and bank deposits actually in existence).

The concept of monetary equilibrium is not universally respected in the economics profession. Some of its critics think that it leads on too readily to the ambitious - and politically controversial - claim that the money supply and money national income tend to move together over time. In fact, any careful statement of the meaning of monetary equilibrium recognizes that there are many influences other than income on the amount of money people want to hold.

Three such influences deserve to be separately identified. The first comes under the general heading of 'payments technology'. The more efficiently payments can be completed, the less money is needed in relation to income. For example, a society in which credit cards are widely used is unlikely to need as much ready cash (in proportion to national income) as one where they are unknown. Also important in this context are such institutional characteristics of the economy as the frequency with which people receive wages and salaries, and the preparedness of companies to defer payments to each other (e.g. by extending trade credit).

Secondly, the rate of interest people and companies receive on money affects how much of it they wish to hold. Interest is not paid at all on notes and coin, and there are still some bank accounts (e.g. the traditional current 
account) which do not pay interest. But nowadays the majority of bank deposits and practically all building society deposits, pay interest. When we are considering people's desire to hold money relative to other assets, the key consideration is the rate of interest received on money relative to the rate of return on these other assets. When the general level of interest rates rises, people will want to cut down on their holdings of notes and coin because the relative attractiveness of these non-interest-bearing assets has declined. But it is possible, indeed quite likely, that the return on interest-bearing bank deposits will have improved relative to the return on other assets, and that people will want to hold a higher ratio of interest-bearing money to income. (We will return later to this point, which has an important bearing on the interest rate sensitivity of the economy.)

Thirdly, it is clear that the expected rate of infiation affects attitudes towards holding money, since every increase in the price level reduces the real value of money balances. A high rate of expected inflation makes it worthwhile to keep wealth in the form of goods and tangible assets rather than money.

In fact, there are so many potential influences that we cannot hope to be comprehensive in a short discussion. But we can give an adequate summary by saying that the desired ratio of money holdings to national income depends on three main considerations: transactions technology, the rate of interest (or, better, the interest rate differential between money and non-money assets) and inflation expectations. If these influences are stable, it is reasonable to expect the desired ratio of money to income to be constant. This is not a particularly bold or ideological statement. It is plain common sense to say that the number of apples people wish to consume depends on how tasty they are, how expensive they are compared to pears and oranges, and how quickly they rot if they are not stored properly. Our remarks on money run on very similar lines. We can analyse the demand for money in much the same way as we analyse the demand for other things.

\section{Some implications of monetary equilibrium}

Once we accept that, with certain conditions satisfied, the desired ratio of money to income is constant, some vital consequences follow. The most important is that an increase of $x$ per cent in the money supply must be followed by an increase of $x$ per cent in money incomes, and so in the nominal value of expenditure and output, if people are again to be happy with their money holdings. If national income does not rise by $x$ per cent immediately, monetary equilibrium has been violated and people will change their behaviour until national income does rise by $x$ per cent. We can think of an increase in national income as having two parts, an increase in output and an increase in the price level. If output is fixed, it is only the price level that can respond 
to the monetary injection. Indeed, monetary equilibrium requires that the $x$ per cent increase in the money supply must be matched by an $x$ per cent increase in the price level.

This does sound like a bold and ideological statement. It is undoubtedly very 'monetarist' in flavour. But our argument does not imply that, in any examination of actual data over a period of years, there will be a precise link between the money supply on the one hand and national income and the price level on the other. First, it has been emphasized that a precise link would be found only if influences such as transactions technology, the rate of interest and inflation expectations were stable. In practice, the character and strength of these influences are always changing, and their changes greatly complicate the relationship between money and prices. Secondly, the statement about money and prices is valid only if monetary equilibrium has been established. We have explained that people are always trying to move towards equilibrium. But in the real world the economy may not be in equilibrium. Just as it takes a period of microeconomic disturbance before the relative price of apples and pears adjusts to the discovery of a new seed or a crop disease, so there may be a period of macroeconomic disturbance before national income and the price level adjust to an increase in the money supply. During this interval of monetary disequilibrium, the connection between money and prices may be difficult to identify.

We will discuss monetary disequilibrium in the next section. But before doing so, some consequences of the argument in the last paragraph need to be emphasized. It is possible both to believe that inflation is always and everywhere essentially 'a monetary phenomenon' (in Friedman's words) and to expect to observe, in the real world, considerable fluctuations in the ratio of money to national income. In policy debates the behaviour of the ratio of money to national income - and of its inverse, the velocity of circulation of money - attracts considerable attention. Many critics of a monetary approach to inflation claim that changes in velocity demonstrate the irrelevance of the money supply. But we can see that these claims are exaggerated and misleading. Indeed, the relevance of the money supply stems, at root, from a belief that the demand for money - like the demand for fruit, building materials or energy - can be analysed with the standard tools of microeconomic theory. All the interesting conclusions about money and prices are derived from the concept of monetary equilibrium. To deny the validity of this concept is also to deny the premise of rationality which is basic to all economic analysis.

\section{The concept of monetary disequilibrium}

The notion of monetary disequilibrium is best understood in relation to that of monetary equilibrium. We have said that when an economy is in equilib- 
rium all prices and quantities set in one period are repeated in the following and subsequent periods. In monetary equilibrium, the demand for money is equal to the money supply and the ratio between money and income is stable over time.

Monetary disequilibrium arises when the demand for money is not equal to the money supply and people are changing their behaviour in order to restore equilibrium. In more familiar language, the amount of money people are willing to hold differs from the amount of money actually in the economy. If people have excess money balances they will seek to reduce them by, for instance, buying goods and services or financial and real assets. Decisions about spending and saving are adjusted until a more settled position, with desired money holdings equal to actual money holdings, is restored.

This may sound strange and, indeed, some economists have questioned the legitimacy of the idea of 'monetary disequilibrium'. In all economies at all times there is a particular quantity of notes, coin and bank deposits in existence, and this quantity is held by people, companies and financial institutions. Surely, the sceptics might say, if the money is held at all, it is held willingly. There cannot be a mismatch between the demand for money and the money supply. In this view, the notion of 'monetary disequilibrium' is incoherent and an intellectual cul-de-sac.

But to dismiss monetary disequilibrium so abruptly is superficial. A modern economy is extremely complex, with millions of prices being fixed every day only to be changed tomorrow, the day after tomorrow and so on into the indefinite future. At any given moment, the price level - and many other characteristics of the economy (including, perhaps, transactions technology, the interest rate and the inflation rate) - may differ from the expectations prevailing when people last took action to adjust their money holdings. Moreover, very few economic agents know precisely how large their money holdings are at every instant in time. It is clear that actual money holdings can differ from the desired level. Monetary disequilibrium is a viable concept. ${ }^{8}$

With this idea accepted as part of our analytical tool-kit, we are almost ready to shift the discussion away from the abstract plane to a practical, realworld level. But there is one further argument to develop. Our interest is in how decisions motivated by the behaviour of credit and money impact on output, employment and prices. We are not particularly interested in the behaviour of credit and money for its own sake. A transfer of money from one bank account to another, or from notes to bank deposits, is tangential to our main concern, since these transactions are purely monetary and do not affect the 'real economy'. It follows that we need to identify and monitor a measure of the money supply which can make people reconsider their patterns of expenditure and saving. There is no point tracking a measure of money which is irrelevant to expenditure decisions. Which measure of money is relevant? 


\section{Narrow money vs broad money}

The notion of monetary disequilibrium gives us the clue to making the right selection. In equilibrium the demand for money is equal to the money supply, monetary variables are neutral in their impact on the economy, and it does not make much difference which particular monetary variable (notes, coin or deposits; M0, M1, M3 or whatever) is the focus of attention. It is only in disequilibrium that money can disturb behaviour. Our question therefore becomes: 'For what measure (or measures) of money is there a possibility that the holdings people want to have differ significantly from the holdings that they actually do have?' This question could be rephrased more briefly as: 'What measures of money can behave in ways which surprise people and make them re-assess their decisions to consume and invest?'.

Notes and coin are the small change of the economy. If people find that their holdings of notes and coin are too small for their requirements (to buy goods and services, mostly), they go to their banks and convert part of their deposits into notes and coin. (If, on the other hand, notes and coin are too large, they leave them on deposit with their banks.) The adjustment occurs through purely monetary transactions, which we have already said are incidental to our main concerns. It is also obvious that no person or business organization allows holdings of notes and coin to affect any major decision about the purchase or sale of large assets (shares, factories, buildings). In an advanced industrial economy, with its massive accumulation of capital assets, these decisions about asset disposition are critical to the economy's behaviour.

We have said enough to reject notes and coin (M0) from consideration. M0 cannot surprise people and make them review their decisions to consume and invest. This narrow aggregate has one further characteristic which needs to be emphasized. We have said that when individuals find that their holdings of notes and coin are out of line with their requirements, they restore equilibrium by transfers into and out of bank deposits. That could leave the banks with too much or too little cash, which creates another problem of adjustment. The banks respond by approaching the Bank of England in order to persuade it either to absorb the excess cash or to eliminate the deficiency. The Bank, which of course issued the notes in the first place, accommodates the banks' requirements as a matter of routine. A large number of individual decisions to increase (reduce) holdings of notes and coin do lead to an increase (reduction) in the aggregate amount of notes and coin in the whole economy. MO adjusts to events in the economy; events in the economy do not adjust to MO.

Nowadays, the contacts between the banking system and the Bank of England are so harmonious, and the Bank's operations are so finely tuned, that the amount of M0 in the economy rarely differs from the amount people want to hold. M0 is virtually always in or near to equilibrium. One conse- 
quence is that econometric work typically identifies a good, close-fitting statistical relationship between $\mathrm{M} 0$ and money national income. ${ }^{9}$ But this does not mean that MO has a strong influence on decisions to spend or on the level of money national income. The direction of causation is rather from money national income to MO.

Similar remarks apply to other measures of narrow money. M1 is larger than M0 because it includes bank accounts which can be spent without giving notice (sight deposits). But, again, if such bank accounts are too large or small, the natural response is to shift a sum of money to or from accounts which require notice (term deposits). An example is when an individual transfers funds from a current account at a clearing bank to a deposit account. This is clearly a financial transaction without implications for the real economy. Moreover, a host of such individual transfers will change the aggregate amount of M1. If M1 is too high or too low in relation to money national income, it is M1 which adjusts, not money national income.

We can summarize the last three paragraphs by saying that the various measures of narrow money are rarely in major disequilibrium, and even when they are, people and companies bring them back into equilibrium by purely monetary transactions. The narrow money aggregates - such as M0 and $\mathrm{M} 1$ - are therefore not the money supply concepts that we are seeking. Instead we need to look at broad money, notably M3 and M4.

\section{Broad money and expenditure decisions}

We have seen that when people and companies have too much or too little narrow money, a more appropriate holding is restored - at the level of the whole economy - by switching between different categories of deposit or between deposits and notes or coin. The position is quite different with broad money. Broad money (on the M3 definition) includes all bank deposits in the economy. If the nominal quantity of such bank deposits is fixed by a separate and independent influence (such as the level of bank credit), a host of individual decisions to switch to and fro between different agents' bank deposits or between one type of bank deposit and another cannot change that nominal quantity. It follows that if the nominal quantity of broad money is too high or too low in relation to income, interest rates or other macroeconomic variables, equilibrium can be re-established only by changes in these variables. This property explains why we must concentrate on broad money, not narrow money, if we wish to understand the link between money and economy activity.

The point may need a little elaboration. Suppose I discover, when I check my bank statement, that my holding of bank deposits is higher than I expected and require. Then I will attempt to shift the excess holding somewhere else. It will not solve the problem to transfer money from a deposit account to a 
current account (or vice versa) since that would leave the total of my deposits unaffected. The only way I can eliminate my excess money is to spend it on goods and services, or acquire an asset. Both these transactions will add to someone else's deposit, but they will not reduce the aggregate amount of bank deposits in the economy. Moreover, although I may eliminate my own excess money holding, the sudden addition of money to someone else's deposit may result in his having excess money holdings. Any one person may think that he can control the amount in his bank account, but:

For all individuals combined, the appearance that they can control their money balances is an optical illusion. One individual can reduce or increase his money balance only because another or several others are induced to increase or reduce theirs; that is, they do the opposite of what he does. If individuals as a whole were to try to reduce the number of dollars [or pounds] they held, they could not all do so, they would simply be playing a game of musical chairs. ${ }^{10}$

This game of musical chairs is the economy's attempt to move from monetary disequilibrium to equilibrium. It is not futile. If everyone considers their broad money holdings excessive, they will all, more or less simultaneously, try to disembarrass themselves of the excess by increasing their spending on goods and services, or by purchasing more assets. These efforts will lead to higher aggregate expenditure and, in due course, probably raise the price level. At the new, higher price level, it may well be that the nominal quantity of bank deposits is again appropriate. Indeed, expenditure decisions will keep on being revised until the right balance between money and incomes is restored. While individuals may be

frustrated in their attempt to reduce the number of dollars [or pounds] they hold, they succeed in achieving an equivalent change in their position, for the rise in money income and in prices reduces the ratio of these balances to their income and also the real value of these balances. The process will continue until this ratio and this real value are in accord with their desires. ${ }^{11}$

We may summarize the message of this section. A large number of individual decisions to increase (reduce) nominal holdings of broad money does not lead to an increase (reduction) in the nominal aggregate amount of broad money, but instead causes changes in expenditure on both current and capital items. The behaviour of the economy therefore adjusts to broad money, rather than broad money to the behaviour of the economy.

\section{Interest rates and prices}

There has now been enough analytical preparation for a rough and ready account of how interest rates, credit and money affect economic activity and 
the price level. It can be related, if rather casually, to the position of the UK economy over the last 20 or 30 years. Let us suppose that the economy is in approximate monetary equilibrium. Interest rates are set at a level where both the growth of credit and the associated growth rate of broad money are such as to keep output expanding at about its trend rate (say, 3 per cent a year) and inflation is at its average value in recent years (say, 5 per cent). Let us also suppose that - perhaps under political pressure to promote faster growth - the Bank of England cuts interest rates substantially. How would we expect the economy to respond?

First, the growth of credit is stimulated. The explanation is simply that with lower interest rates the attractions of borrowing are increased. If interest rates are cut, there will be a wider range of assets where the return exceeds interest costs and there will also be higher borrowing. Experience in the UK suggests that two kinds of credit - mortgage borrowing for residential property and borrowing by property companies to invest in offices and other kinds of commercial property - are particularly susceptible to interest rate changes. Increased expenditure on these assets often represents the economy's earliest 'real' response to lower interest rates.

Secondly, the faster growth of credit leads to faster growth of broad money. If broad money growth was previously appropriate to maintain a steady rate of increase in money national income of about 8 per cent a year (i.e. 3 per cent increase in output, 5 per cent increase in prices), it must now be too high. Economic agents discover - because of the quicker increase in the nominal amount of bank deposits - that their money holdings are excessive. For this reason they must think about how their money holdings can be brought into a better relation to their expenditure and income.

But there is yet another reason for adjusting behaviour. As mentioned earlier, in the UK today most deposits are interest-bearing. When interest rates are cut, the desired ratio of interest-bearing deposits to income is lowered. This effect would stimulate expenditure even if the nominal amount of broad money were constant. Since there is actually more rapid growth of nominal money due to the extra buoyancy of bank credit, the urge to move out of money assets into either current expenditure or non-money assets is doubly strong.

We have explained - in the last section - why the excess holdings of broad money cannot be eliminated except by changes in incomes, interest rates or other macroeconomic variables. In practice, the economy's efforts to restore monetary equilibrium are very complicated and work initially via asset markets (the stock market, the property market) rather than goods markets (i.e. through immediate changes in consumption and investment). For example, when they have 'too much' money in the bank, private individuals switch much of the excess balances to building societies (where they 
finance the purchase of houses), to financial institutions such as unit trusts and insurance companies (where they become available to buy shares and government bonds) and to companies. Companies can then use the money either to finance stockbuilding and investment, or to purchase more assets (the shares of other companies, or commercial and industrial property such as offices, warehouses and factories). Typically, in the early stages of an upturn, when there is only nascent optimism about future output growth, companies are more eager to buy existing assets than commit themselves to increased expenditure on new capital equipment and buildings.

In other words, a cut in interest rates is often followed in the first instance more by a surge in asset values than by an upturn in output growth. But just as there is an equilibrium relationship between money and national income, so there are an assortment of equilibrium relationships between the market values of capital assets and their replacement values. If the market value of capital assets is driven far in excess of replacement value by a boom in credit and money, more new investment becomes worthwhile. To talk in terms of 'market value' and 'replacement value' may sound technical, but the underlying economic logic is obvious. After all, if house prices soar above the cost of building new ones, it is only common sense that there should be a surge in housebuilding. In due course, the jump in asset values stimulates higher investment.

The length of the lag between the interest rate cut and the revival in most forms of capital expenditure may confuse economists into thinking that investment - and therefore the economy as a whole - is not sensitive to interest rate changes. Indeed, it needs to be recognized that a standard feature in the early stages of a boom is that only one kind of investment, in private residential houses, is notably strong. Consumers' expenditure, which is often regarded by economists as little affected by interest rates, may show a more definite response than investment. Closer examination is nevertheless likely to demonstrate that the increase in consumption is concentrated in long-lived items like cars and durables (e.g. furniture, carpets, washing machines). These items are effectively investment by the personal sector and the increased demand for them may be motivated, in large part, by the cut in interest rates.

Once the boom has started it becomes difficult to stop. Indeed, the rise in asset values which reflects attempts to redispose wealth holdings more effectively may give further impetus to credit demand. Some businessmen may be tempted to project a rate of asset price appreciation persistently above the rate of interest, and they borrow even more heavily to capture the expected capital gains. Unless interest rates are raised, speculative excitement becomes self-feeding. Credit growth - and therefore the growth of broad money accelerates further. 
Eventually the economy reaches a condition of boom. The rate of real demand growth may be between 5 and 7 per cent a year, far in excess of the 3 per cent trend growth rate. Output may grow at an above-trend rate of 5 or even 6 per cent for a time, but in due course signs of strain emerge. In the UK, which has a medium-sized economy highly exposed to international influences, a classic symptom of excess demand is balance-of-payments deterioration. But other indicators, such as a sharp fall in unemployment and a rise in the proportion of companies reporting capacity shortages, usually tell the same story. The lack of spare capacity in factories now leads to the rapid growth in manufacturing investment which was missing at an earlier stage in the cycle.

Companies and individuals are, throughout the upswing and the boom, attempting to bring their money holdings into line with their incomes. But with credit growth strengthening because of the emergence of speculative activities in the property and other asset markets, they may find that every time they adjust their behaviour, a new and unexpected addition to their bank deposits throws them out of equilibrium again. The ratio of broad money to their incomes may rise to levels far above the long-run figure they regard as sensible. To put the same point in more technical terms, the velocity of circulation of M3 and M4 may fall substantially beneath its equilibrium value. Strangely, a repetitive pattern in UK cycles at this stage indeed, virtually a recurrent cyclical phenomenon in its own right - is that economic commentators point to the drop in velocity as evidence of the poor relationship between the money supply and economic activity.

Sooner or later inflation spreads from asset markets to the prices of goods leaving factories and appearing in the shops. The excess demand for all types of products causes shortages which can only be eased by price increases; the decline in unemployment leads to tightness in the labour market, which provokes higher wage increases and aggravates the spiral in industrial costs; and the worsening external payments position undermines the pound on the foreign exchanges, which increases the price of imported goods, including the costs of many of the raw materials and inputs used in UK factories. At this point the growth rates of $\mathrm{MO}$ and $\mathrm{Ml}$ - which were probably unaffected by the asset price surges in the early stages of the boom, but are highly responsive to the higher money value of transactions consequent on rising inflation - may accelerate markedly.

Now, with inflation as well as real output growth moving above its previous trend figure, the Government becomes alarmed. It mandates the Bank of England to raise interest rates to restrain the pace of expansion. The higher level of interest rates causes falls in asset prices and deters the more speculative forms of credit. But broad money growth remains high for several quarters, as companies complete the expansion programmes initiated during 
the boom and take up banking facilities already arranged. Beneath-trend output growth of under 3 per cent is needed for a time to compensate for the excesses of the boom. If the Government is lucky, credit expansion, money growth and inflation return - without too much fuss or delay - to the values associated with the previous condition of approximate monetary equilibrium. However, the price level is $x$ per cent higher than it would have been if interest rates had not been cut in the first place. The value of $x$ is likely to be very close to the excess of broad money growth over the figure that would have occurred if interest rates had been kept constant throughout. The episode of excessive credit and monetary expansion has achieved nothing positive in real terms. But it has imposed on society, even if only temporarily, all the awkwardness and inconvenience of coping with higher inflation.

\section{Conclusion: money does matter}

The sequence of events described in the last section may sound familiar. It is, in the form of a simplified idealization, the story of the UK economy between mid-1986 and mid-1988. The early 1980 s had been a rather tranquil period for the UK economy, as output grew at about the trend rate of $2^{3 / 4} \mathrm{per}$ cent a year and inflation was steady at about 5 per cent. But a marked upturn in demand and output growth in the second half of 1986 followed a reduction in interest rates from the rather high levels of 1985 (when clearing banks' base rates averaged $12 \frac{1}{4}$ per cent). It gathered dangerous momentum in early 1988 after base rates had dropped to $8 \frac{1}{2} 2$ per cent and below. Share prices soared in the initial phase of above-trend output growth, while property values rose sharply throughout the boom. Serious financial problems eventually emerged, with inflation on the rise and the current account of the balance of payments lurching heavily into deficit. Between June and August 1988 base rates were raised eight times from $7 \frac{1}{1} / 2$ per cent to 12 per cent, as the Bank of England tried to compensate for previous monetary looseness.

The behaviour of both real and financial variables during this period is inexplicable except in terms of interest rates, credit and broad money. Some economists have suggested other causes for the rapid expansion of demand and output, but these are all implausible. The world economy was not notably vigorous over these years and, in any case, such strength as it had cannot account for the UK growing faster than the rest of the industrial world. Fiscal policy was somewhat contractionary in effect, even when adjustment is made for the impact of cyclically strong tax revenues in forging a large budget surplus. The claim that the oil price fall of 1986 caused a significant sterling depreciation, which then stimulated exports, is valid up to a point. ${ }^{12}$ But over the two years to mid-1988 imports rose much faster than exports and the change in the balance of payments actually withdrew demand from the economy. The non-monetary explanations of the 1986-8 boom (which 
may be fairly called the 'Lawson boom' after the Chancellor of the Exchequer who presided over it) are random and miscellaneous; the monetary explanation - which focuses on official interest rate decisions, the upturn in credit expansion in late 1985 and 1986, and the subsequent acceleration in broad money growth - fits the essential facts.

Indeed, the Lawson boom has several incontestable similarities to the Barber boom of 1971-3 and what might be termed the 'Healey boomlet' of 1977-9. At some point in all three of these episodes, base rates dipped beneath 8 per cent and gave a clear stimulus to credit and monetary expansion. Apart from these instances, base rates were never at 8 per cent or less in the 17 years from 1971. The year 1971 is an important landmark since it saw the abolition of artificial restrictions on bank balance sheet growth. When the low level of interest rates had been established, share and property prices rose quickly, demand and output moved forward at above-normal rates, and financial difficulties developed. Interest rates then had to be raised to cool the economy down.

If the general outline of our analysis is accepted, it is evident that the Bank of England has enormous power over the economy. Interest rates are under its absolute control, while interest rate changes cause fluctuations in the growth of credit and broad money, and these in turn cause fluctuations in the growth of demand and output. The Bank of England may abuse its power, perhaps under pressure from over-optimistic Chancellors of the Exchequer. But there should be no doubt about the extent of its ability to determine macroeconomic outcomes. It would be of great benefit to society if the Bank of England's power were exercised more responsibly in future than it has been in recent years.

\section{Notes}

1. Strictly, changes in the quantity of money are matched by changes in output and the price level. The effect on prices dominates only in an inflationary economy, where the rate of increase in prices is two, three or more times the rate of increase in output. See pp. 116-20 of Sir Alan Walters's Britain's Economic Renaissance (Oxford: Oxford University Press, 1986) for an example of the claim that money and credit are frequently confused.

2. 'Central bank' is a generic term for the bankers' bank. Nowadays it is invariably banker to the Govemment and its note liabilities are legal tender. But there is nothing preordained about these arrangements which, have evolved over centuries. See Tim Congdon, 'Is the provision of a sound currency a necessary function of the state?', pp. 2-21 in National Westminster Bank Quarterly Review (August 1981), for an outline of the historical development of the existing system.

3. Monetarist economists are known for emphasizing that control of the money supply is necessary and sufficient for the control of inflation. Associated with this essentially technical proposition are a number of political beliefs, including a particularly hostile attitude towards state intervention in the economy.

The author registered his own protest against the failure to differentiate between commodity and paper-money economies in his 'Has Friedman got it wrong?', pp. 117- 
25 in The Banker (July 1983). The same theme appears in Kaldor's 1980 evidence to the House of Commons Treasury and Civil Service Committee, reprinted in N. Kaldor, The Scourge of Monetarism (Oxford: Oxford University Press, 1986).

4. There is a trivial exception. The Scottish banks issue notes which, although they are perfectly acceptable for most payments throughout the UK, are not legal tender.

5. In practice, the Bank of England expresses its wishes on interest rates more by setting the price at which it buys and sells seven-day bills (seven-day dealing rate) than by announcing the rate of interest at which it will lend money. The detailed institutional arrangements for money market operations are extremely complicated, but it would not change the basic argument if they were described here. The two key articles are: 'The management of money day by day', in Bank of England Quarterly Bulletin (March 1963) and 'The role of the Bank of England in the money market', in Bank of England Quarterly Bulletin (March 1982). They are reprinted in the Bank of England's The Development and Operation of Monetary Policy (Oxford: Oxford University Press, 1984).

6. This statement is intended as a direct contradiction of the general argument in Chapters 3 and 4 of J. C. R. Dow and I. D. Saville, A Critique of Monetary Policy (Oxford: Oxford University Press, 1988), and of the particular statement on p. 61 that "bank base rates are determined by conventions that are largely historically determined, and thus subject to considerable inertia'.

7. The view that short-term interest rates are strongly influenced by market sentiment, and are not therefore under full Bank of England control, has been argued by Professors David Llewellyn and Brian Tew in 'The Sterling Money Market and the Determination of Interest Rates', in National Westminster Bank Quarterly Review (May 1988).

8. The idea of disequilibrium money is associated in the UK at present particularly with Professor Charles Goodhart of the London School of Economics and Professor David Laidler of the University of Western Ontario. See, for example, Chapter 10 of C. A. E. Goodhart, Monetary Theory and Practice (London: Macmillan, 1984). But it can be traced back a long way. Arguably, it is implicit in the distinction between long-run and short-run monetary equilibria in D. Patinkin, Money, Interest and Prices, 2nd edn (New York: Harper \& Row, 1965), particularly on pp. 50-9, and perhaps can be found in Keynes (notably, according to Richard Coghlan, in two articles Keynes wrote in 1937). (See R. T. Coghlan, Money, Credit and the Economy (London: Allen \& Unwin 1978, p. 27).

9. See, as regards M0, R. B. Johnston, The Demand for Non-Interest-Bearing Money in the UK (London: Government Economic Service Working Paper, No. 66, H.M. Treasury, 1984) and, for M1, R. T. Coghlan, 'A transactions demand for money', Bank of England Quarterly Bulletin (March 1978).

10. See M. Friedman, 'Statement on monetary theory and policy' given in Congressional hearings in 1959, reprinted on pp. 136-45 of R.J. Ball and Peter Doyle (eds), Inflation (Harmondsworth: Penguin Books, 1969). The quotation is from p. 141.

11. Again, the quotation is from p. 141 of Friedman, 'Statement on monetary theory and policy'.

12. As argued by $\mathrm{Mr}$ Philip Stephens, the Economics Correspondent of the Financial Times, in an article in the Financial Times of 6 August 1988. 
The Importance of Money in Macroeconomic Forecasting - Part 2

From an article 'A new and compleat economic model for the Chancellor' from The Spectator of 11 March 1989.

This article was a sequel ('part 2)' to that on the Treasury's forecasting failures in the early 1970s, published in The Times of 28 August 1975. (See pp. 30-35.)

As the annual pre-Budget guessing game becomes more technical by the day, it needs to be remembered that the 1988 Budget was a disaster for the clever civil servants who advise the Chancellor. The economic forecast published by the Treasury with the Budget last year was so wrong as to make a mockery of the considerable effort, in terms of professional time, bureaucratic manpower and computer gadgetry, which went into producing it. Indeed, the mistakes were so large as to cast doubt on the legitimacy of the whole exercise.

The official view was that there would be a significant slowdown in output growth from $4 \frac{1}{2}$ per cent in 1987 to 3 per cent in 1988, with only a mild deterioration in the balance of payments from a current account deficit of $£ 2.5$ billion in 1987 to $£ 4$ billion in 1988 . In the event, national output again grew by about $4^{1 / 2}$ per cent and the balance of payments lurched into massive deficit, with the current account deficit reaching $£ 14$ billion. The net effect of these errors is that the Treasury underestimated the growth of domestic demand by almost 5 per cent of national output. A mistake on this scale - equivalent to more than one year's normal growth - can be fairly described as gross professional incompetence. Parallels in other walks of life would be a civil engineering contractor building one more storey on an office building than in the architect's plans, or a doctor telling a patient that he has mild angina just before he suffers a massive heart attack.

The blunders were not just in predicting demand, output and the balance of payments. The forecasts of financial variables were also completely adrift. Whereas the official Budget-time view was that 1988 would see stable inflation and little change in interest rates, the increase in the retail price index went up from 4 per cent at the end of 1987 to $6^{1 / 2}$ per cent at the end of 1988 , and clearing bank base rates soared from $81 / 2$ per cent in March to 13 per cent in November. If one believes with Mr Lawson that high interest rates are a cure-all for excess demand, the incompetence of the Treasury's forecast is re-emphasized. The move to higher base rates ought to have caused the growth in demand to be smaller than expected, but it turned out to be more.

The Treasury was embarrassed by last year's events, but private sector economists ought to be even more apologetic. For 1988 was a catastrophe 
not just for the Government's advisers in Whitehall, but for British macroeconomics. At the beginning of the year the average of City forecasts was that growth would be a little beneath 3 per cent and inflation lower than 4 per cent. Although the City 'scribblers' have been derisive about $\mathrm{Mr}$ Lawson, their view was for less even growth and less inflation than the Treasury's estimates; they were actually more inaccurate than the Chancellor. According to Mr Christopher Smallwood writing in The Sunday Times, 'For economic forecasters 1988 will go down as the annus horrendus. It was the year they all got it wrong. And not just a little bit wrong, but spectacularly wrong.'

But this is an exaggeration. They did not all get it wrong. There was an exception. In late 1986 my economics team at the stockbrokers, L. Messel \& Co. prepared a forecast which argued that, without big changes in Government policy, the next two years would see a boom in output followed by an intensification of inflationary pressures. The forecast was not perfect, and indeed it could not have been, since there is always much that is uncertain about government policy, the world economy, the oil market and the like. But it did capture the main features of the economy in 1987 and 1988.

The forecast was updated quarterly, to reflect new data and policy developments. (It also appeared under a different name, as L. Messel \& Co. was integrated into the American securities house, Shearson Lehman Hutton. The detailed statistical work was done by Dr Peter Warburton, who has since moved to Robert Fleming Securities.) In February 1988 we envisaged $3 \frac{1}{2} 2$ to 4 per cent growth in output, retail price inflation of $6^{1 / 2}$ per cent, short-term interest rates by the end of the year of 12 per cent, and a large current account deficit of $£ 6$ billion. These numbers were not 100 per cent exact, but they proved to be broadly right. In particular, we made the key strategic judgement that the pace of spending growth would accelerate unless interest rates were raised substantially. This point was essential in understanding what was to happen in the rest of the year.

The important issue here is: why were our forecasts right (more or less) and the mass of other forecasters so badly wrong? If it were simply a matter of good guesswork and better luck, there would not be much more to say. If the forecasting game were largely random, every participant would have a brief moment of glory like this. But there is another possibility - that our model for forecasting the economy was different from and superior to that used by other economists. If so, the approach we adopted should in future be able to provide, on a fairly systematic basis, better insights into how the economy works.

In fact, our approach was quite different, and we were very self-conscious about it. In a standard model, output is determined by total spending in the economy and total spending is seen as the sum of various components of 
demand, such as consumption, investment and exports. Equations are used to calculate the most likely values of these components, on the assumption that underlying behaviour will be the same in future as in the past. It is a characteristic of the standard models that financial variables such as money supply growth are seen as being determined by, rather than determining, spending, while interest rates have only weak effects on the demand components. As a result, the standard models regard interest rates, credit growth and the money supply as trivial and subordinate. The prices of such assets as houses, shares and industrial and commercial property are also largely ignored. (One mainstream forecaster told me about 18 months ago, just as the house price boom was gathering dangerous momentum, that house prices were 'a fifth wheel' in any forecasting exercise.)

By contrast, our model started with interest rates, which were taken as being determined by the Bank of England. The level of interest rates was judged to be a powerful influence on credit to the private sector, particularly mortgage credit. Since every new bank loan creates a new bank deposit, credit growth determined the growth of the money supply. (The money supply, on its broad definition, is dominated by bank deposits.) Unexpected changes in the money supply then made people and companies alter their spending patterns, with strong effects on both asset prices and the demand components which comprise total spending. In two respects, therefore, our model diverged radically from that used by other forecasters. First, the financial variables drove the real variables forward, rather than the other way round. Secondly, changes in broad money were central to the economy's behaviour.

All these technicalities may sound complicated and tedious, and of only marginal relevance to the political debate. In fact, they are crucial to understanding the future of both economic policy and the politicians who shape it. The skirmish between our forecast and the standard forecast over the last two years has been another episode in the protracted intellectual battle fought between Keynesians and monetarists since the early 1970s. The standard forecast was derived from a model in which money does not really matter, whereas our forecast was based on a model in which money mattered vitally. The breakdown of the conventional models and the success of our alternative approach suggest that the money supply (on the much despised broad definitions, M3 and M4) remains as important now as it was when the monetarists first presented their case.

This is not the first humiliation suffered by the standard models. In 1974 and 1975 they completely failed to recognize the scale of the inflationary threat implicit in the monetary growth of the Heath-Barber boom and to appreciate just how bad a recession would be needed to bring inflation down again. Interestingly, a small group of monetarists at Manchester University, 
under the leadership of Professors David Laidler and Michael Parkin, were the only economists who predicted both the rise in inflation to over 20 per cent and a sharp fall in output.

The Heath-Barber boom was a watershed in Britain's post-war political economy. It was as a reaction to the wild monetary adventurism of 1972 and 1973 that Sir Keith Joseph gave his Preston speech of September 1974 which insisted that, 'our inflation has been the result of the creation of new money...out of proportion to the additional goods and services available. When the money supply grows too quickly, inflation results. This has been known for centuries.' The Preston speech was effectively the beginning of Thatcherism as a political movement. By 1979 it had become a cliché that monetary control was integral to contemporary Conservativism.

This intellectual environment gave Nigel Lawson, with his unusually extensive knowledge of the economy, based on many years as a financial journalist, the opportunity to cultivate a reputation as an expert on monetary questions. He became Thatcherism's financial technician. As Financial Secretary to the Treasury in the early years of the Thatcher Government, he championed strict control of broad money as the key to inflation control. But, as Chancellor in the mid-1980s, he appeared to renounce what he had once stood for. He scrapped broad money targets and engineered the greatest surge in private sector credit this country has ever seen. The boom made him popular for a time. But the inevitable sequel of rising inflation and balanceof-payments deterioration has now tarnished his reputation, probably for good.

There is a growing enigma about Mr Lawson's performance and motives. It would be easy to attribute the somersault in his policies to an excess of political cynicism, a lack of economic understanding or simple folly. But there may be a more straightforward and charitable explanation. This is to see the Chancellor as someone highly susceptible to the latest advice from the clever Treasury civil servants who prepare the official economic forecasts. If so, there is an obvious need for British macroeconomists to change the way they analyse the economy and to incorporate monetary variables more fully into their models. Unless this is done, the next Chancellor - who will have a weaker grasp of technicalities than Mr Lawson - may be misled even more badly by his advisers. 